\title{
PENGARUH PENERAPAN QUANTUM TEACHING TERHADAP PENINGKATAN KEMAMPUAN PENALARAN MATEMATIKA PADA MAHASISWA CALON GURU
}

\author{
${ }^{1}$ Vevi Hermawan, ${ }^{2}$ Agus Dede Anggiana \\ ${ }^{1,2}$ Universitas Pasundan \\ 1vevi_pmat@unpas.ac.id
}

\begin{abstract}
ABSTRAK
Quantum Teaching menciptakan lingkungan belajar yang efektif, dengan cara menggunakan unsur yang ada pada siswa dan lingkungan belajarnya melalui interaksi yang terjadi di dalam kelas interaksi serta proses pembelajaran yang tercipta akan berpengaruh besar sekali terhadap efektivitas dan antusiasme belajar pada peserta didik. Dengan penerapan metode ini, diharapkan guru akan lebih mencintai dan lebih berhasil dalam memberikan materi serta lebih dicintai anak didik karena guru mengoptimalkan berbagai metode. Tujuan penelitian ini, yaitu untuk mengetahui peningkatan kemampuan penalaran matematika siswa yang menggunakan penerapan Quantum Teaching, maka metode yang digunakan adalah metode eksperimen. Rerata skor pretes siswa kelompok eksperimen $(5,13)$ dan kelompok kontrol $(5,21)$ relatif sama. Hal tersebut ditunjukkan oleh perbedaan rerata yang hanya 0,08. Namun rerata skor posttes siswa kelompok eksperimen $(8,68)$ dan kelompok kontrol $(7,13)$ berbeda sebesar 1,55 . Kenaikan rerata skor posttes dari skor pretes kelompok eksperimen 3,55, dan kenaikan rerata skor posttes dari skor pretes kelompok kontrol hanya 1,92. Hasil Uji signifikansi terhadap perbedaan rerata skor postes kelompok eksperimen dengan rerata skor postes kelompok kontrol diperoleh bahwa, dalam tingkat keberartian $\alpha=0,05$ secara meyakinkan terdapat perbedaan yang signifikan antara rerata skor postes kelompok eksperimen dengan rerata skor posttes kelompok kontrol. Peningkatan rerata hasil kemampuan penalaran mahasiswa kelas ekperimen lebih besar daripada rerata hasil kemampuan penalaran mahasiswa kelompok kontrol, sehingga dapat diketahui bahwa quantum teaching lebih berpengaruh secara signifikan daripada pembelajaran konvensional dalam meningkatkan kemampuan penalaran mahasiswa calon guru.
\end{abstract}

Kata Kunci: Penalaran Matematik, Quantum Teaching

\begin{abstract}
Quantum Teaching creates an effective learning environment, by using existing elements in students and their learning environment through interactions that occur in the classroom interactions as well as the learning process created will greatly influence the effectiveness and enthusiasm of learning in students. With the application of this method, teachers are expected to be more loving and more successful in providing material and are more loved by students because the teacher optimizes various methods. The purpose of this study, namely to find out the improvement of students' mathematical reasoning abilities using the application of Quantum Teaching, the method used is an experimental method. The mean pretest scores of the experimental group students (5.13) and the control group (5.21) were relatively similar. This is indicated by the average difference of only 0.08 . However, the mean posttest scores of the experimental group students (8.68) and the control group (7.13) differed by 1.55. The average increase in posttest scores from the experimental group pretest scores was 3.55, and the increase in posttest scores from the control group pretest scores was only 1.92. Significance Test Results for the difference in mean scores of the experimental group posttest with the mean score of the posttest control group obtained that, in
\end{abstract}


the significance level $\alpha=0.05$ conclusively there was a significant difference between the mean posttest score of the experimental group with the mean posttest score of the control group. The increase in the mean results of the reasoning ability of the experimental class students was greater than the mean results of the reasoning ability of the control group students, so that it could be seen that quantum teaching had a more significant effect than conventional learning in increasing the reasoning ability of prospective teacher.

Keywords: Reasoning, Quantum Teaching, Scientific

\section{PENDAHULUAN}

Peningkatan kualitas pendidikan dapat dilihat dari bagaimana pendidik itu mengajar dan tingkat kesejahteraan pendidik tersebut.Selain itu, kualitas pendidik pun harus sesuai dengan kurikulum yang selalu diperbaharui dan sesuai dengan kemajuan zaman serta ditunjang oleh sarana dan prasarana yang memadai, karena pendidikan itu dilakukan sedini mungkin hingga akhir hayat.

Matematika adalah salah satu ilmu hitung. Mempelajari Matematika berarti mempelajari perhitungan. Jarang sekali orang yang menyukai ilmu ini dengan beragam alasan yang berbeda-beda. Menurut banyak orang matematika membosankan dan tidak menarik, sampai ada yang mengatakan mempelajari matematika akan membuat kepala pusing.

Banyak orang yang memandang matematika sebagai bidang studi yang paling sulit.Seperti yang dikemukakan Ruseffendi (1991:15), "Matematika (ilmu pasti) bagi anak-anak pada umumnya merupakan mata pelajaran yang tidak disenangi, kalau bukan merupakan sarana untuk memecahkan masalah dalam kehidupan sehari-hari”.

Sering kali orang mempertukarkan antara matematika dengan aritmetika atau berhitung.Padahal matematika memiliki cakupan yang lebih luas daripada aritmetika.Aritmetika hanya salah satu cabang ilmu dari matematika, yaitu salah satu cabang ilmu dari matematika yang mempelajari tentang perhitungan.

Dalam pembelajaran matematika, disadari bahwa berbagai kemampuan atau kecerdasan yang ada pada diri seseorang utamanya seorang siswa akan tereksploitasi. Ruseffendi (2006:111-112) dalam bukunya menyatakan bahwa diantara kemampuan atau kecerdasan itu, "adalah kemampuan memusatkan perhatian, kemampuan mengambil makna, kemampuan mengemukakan pendapat, kemampuan belajar cepat, kemampuan mengingat-ingat, dan kemampuan penalaran”. Kemampuan-kemampuan tersebut nantinya akan menunjang bagi tercapainya tujuan pembelajaran, utamanya dalam pembelajaran matematika. 
Salah satu dari beberapa tujuan pembelajaran matematika adalah untuk melatih cara berpikir dan bernalar dalam menarik kesimpulan. Penalaran merupakan bagian dari matematika yang sangat penting karena penalaran merupakan terjemahan dari reasoning. Penalaran merupakan salah satu kompetensi dasar matematik disamping pemahaman, komunikasi dan pemecahan masalah. Penalaran juga merupakan proses mental dalam mengembangkan pikiran dari beberapa fakta atau prinsip. Penalaran dapat memberikan kontribusi yang signifikan terhadap hasil dari pendidikan matematika.

Quantum Teaching menciptakan lingkungan belajar yang efektif, dengan cara menggunakan unsur yang ada pada siswa dan lingkungan belajarnya melalui interaksi yang terjadi di dalam kelasinteraksi serta proses pembelajaran yang tercipta akan berpengaruh besar sekali terhadap efektivitas dan antusiasme belajar pada peserta didik.

Jika metode ini diterapkan, maka guru akan lebih mencintai dan lebih berhasil dalam memberikan materi serta lebih dicintai anak didik karena guru mengoptimalkan berbagai metode, apalagi dalam Quantum Teaching ada istilah 'Bawalah dunia mereka ke dunia kita, dan hantarlah dunia kita ke dunia mereka'.Hal ini menunjukkan, betapa pengajaran dengan Quantum Teaching tidak hanya menawarkan materi yang mesti dipelajari siswa.Tetapi jauh dari itu, siswa juga di ajarkan bagaimana menciptakan hubungan emosional yang baik dalam dan ketika belajar. Selain itu, ada beberapa prinsip Quantum Teaching, yaitu: (1) segalanya berbicara, lingkungan kelas, bahasa tubuh, dan bahan pelajaran semuanya menyampaikan pesan tentang belajar; (2) segalanya bertujuan, siswa diberi tahu apa tujuan mereka mempelajari materi yang kita ajarkan; (3) pengalaman sebelum konsep, dari pengalaman guru dan siswa diperoleh banyak konsep; (4) Akui setiap usaha, menghargai usaha siswa sekecil apa pun. Jika layak dipelajari, layak pula dirayakan, kita harus memberi pujian pada siswa yang terlibat aktif pada pelajaran kita.

Lebih jauh, dunia pendidikan akan semakin maju ke depannya. Sebab, Quantum Teachingakan membantu siswa dalam menumbuhkan minat siswa untuk terus belajar dengan semangat. Apalagi Quantum Teaching juga sangat menekankan pada pentingnya bahasa tubuh.Seperti tersenyum, bahu tegak, kepala ke atas, mengadakan kontak mata dengan siswa dan lain-lain.Citarasa menyenangkan seperti humor dilakukan dengan maksud agar KBM tidak membosankan

Berdasarkan pertimbangan di atas, peneliti memilih penggunaan Quantum Teaching sebagai alternatif solusinya. Quantum Teaching berupaya menciptakan suasana belajar yang kondusif (nyaman dan menyenangkan), dinamis, interaktif dan setiap siswa penuh percaya diri.Quantum Teaching menekankan bahwa interaksi dalam pembelajaran 
sangat penting karena dapat mengubah energi menjadi cahaya yang berarti kesuksesan pribadi maupun bersama.

Mengingat keterbatasan dalam berbagai hal dan untuk menghindari meluasnya masalah serta agar penelitian ini lebih terarah dan memberikan gambaran yang jelas mengenai masalah yang diteliti, maka penelitian ini perlu dibatasi. Penelitian ini hanya dibatasi pada subjek penelitian yaitu mahasiswa calon guru FKIP Unpas, konsep matematika yang dibahas dalam penelitian, penerapan Quantum Teaching, dan analisis peningkatan kemampuan penalaran matematika mahasiswa melalui tes awal (pretest) dan tes akhir (posttest).

\section{METODE PENELITIAN}

Sesuai dengan tujuan penelitian ini, yaitu untuk mengetahui peningkatan kemampuan penalaran matematika siswa yang menggunakan penerapan Quantum Teaching, maka metode yang digunakan adalah metode eksperimen.

Ada dua kelompok kelas yang diperlukan. Dua kelompok kelas ini dipilih secara acak dari semua kelas X yang ada. Kelompok kelas pertama dinamakan kelas eksperimen, dan kelompok kelas kedua dinamakan kelas kontrol. Kedua kelompok kelas diberikan tes awal (pretest) dan tes akhir (posttest). Kelas eksprimen memperoleh pengajaran matematika yaitu dengan penerapan Quantum Teaching, sedangkan kelas control memperoleh pengajaran matematika dengan menggunakan pembelajaran biasa (konvensional) sebagai perlakuan.

Berdasarkan uraian di atas, maka disain eksperimen penelitiannya adalah disain pretest - posttestkelompokkontrol. Adapun bagan disain penelitiannya adalah sebagai berikut :

$\begin{array}{llllll}\text { Kelas Eksperimen } & : & \mathbf{A} & \mathbf{O}_{1} & \mathbf{X}_{1} & \mathbf{O}_{2} \\ \text { Kelas Kontrol } & : & \mathbf{A} & \mathbf{O}_{1} & \mathbf{X}_{2} & \mathbf{O}_{2}\end{array}$

Keterangan:

$\mathrm{A}=$ Pemilihan sampel secara acak

0 = Soal-soal untuk tes awal (pretest) dan tes akhir (posttest) sama

$\mathrm{X}_{1}=$ Penerapan Quantum Teaching

$\mathrm{X}_{2}=$ Perlakuan biasa (Pembelajaran Konvensional) 


\section{HASIL DAN PEMBAHASAN}

Hasil uji-t penalaran matematis pada saat pretes yaitu bahwa nilai signifikansi (Pvalue) untuk faktor pembelajaran sebesar 0,675 > 0,05 maka H0 diterima. Dengan kata lain, tidak terdapat perbedaan rerata skor pretes penalaran matematis mahasiswa antara kelompok kontrol dan kelompok eksperimen berdasarkan faktor pembelajaran. Akan tetapi, hasil uji perbedaan rerata posttes penalaran matematis mahasiswa yaitu bahwa nilai signifikansi (P-value) untuk faktor pembelajaran sebesar 0,000 $<0,05$ maka H0 ditolak. Dengan kata lain, terdapat perbedaan rerata skor posttes penalaran matematis mahasiswa antara kelompok kontrol dengan kelompok eksperimen. Adapun hasil perhitungan uji perbedaan rerata dapat dilihat pada tabel berikut ini.

Tabel 1. Hasil Pengujian Perbedaan Rerata Penalaran Matematis Mahasiswa

\begin{tabular}{llllllll}
\hline Tes & Pembelajaran & Perbedaan & Thitung & Df & ttabel & Sig. & H0 \\
\hline Pretes & Eksperimen-kontrol & $5,13<5,21$ & 0,313 & 38 & 2,024 & 0,675 & Diterima \\
Postes & Eksperimen-kontrol & $8,68>7,13$ & $-6,308$ & 38 & 2,024 & 0,000 & Ditolak
\end{tabular}

Jika dilihat dari tabel 5 di atas, rata-rata skor pretes kemampuan penalaran matematis mahasiswa kelompok eksperimen dan kontrol masing-masing adalah adalah 5,13 dan 5,21. Berdasarkan hasil uji perbedaan rata-rata diperoleh bahwa rata-rata kedua kelompok tersebut tidak memiliki perbedaan yang signifikan. Dalam hal ini dapat disimpulkan bahwa kemampuan awal penalaran matematika mahasiswa kelompok eksperimen dan kelompok kontrol adalah sama.

Setelah dilakukan treatment (perlakuan) terhadap kelompok eksperimen dengan menggunakan quantum teaching dan kelompok kontrol dengan menggunakan pembelajaran konvensional, maka diperoleh rata-rata skor postes kelompok eksperimen adalah 8,68 dan kelompok kontrol adalah 7,13. Dengan memperhatikan rata-rata skor posttes antara kelompok eksperimen dan kelompok kontrol dapat disimpulkan bahwa kemampuan penalaran matematis kelompok eksperimen lebih baik daripada kelompok kontrol secara signifikan.

Rerata skor pretes siswa kelompok eksperimen $(5,13)$ dan kelompok kontrol $(5,21)$ relatif sama. Hal tersebut ditunjukkan oleh perbedaan rerata yang hanya 0,08. Namun rerata skor posttes siswa kelompok eksperimen $(8,68)$ dan kelompok kontrol $(7,13)$ berbeda sebesar 1,55. Kenaikan rerata skor posttes dari skor pretes kelompok eksperimen 3,55, dan kenaikan rerata skor posttes dari skor pretes kelompok kontrol hanya 1,92.

Hasil Uji signifikansi terhadap perbedaan rerata skor postes kelompok eksperimen dengan rerata skor postes kelompok kontrol diperoleh bahwa, dalam tingkat keberartian $\alpha$ 
$=0,05$ secara meyakinkan terdapat perbedaan yang signifikan antara rerata skor postes kelompok eksperimen dengan rerata skor posttes kelompok kontrol. Peningkatan rerata hasil kemampuan penalaran mahasiswa kelas ekperimen lebih besar daripada rerata hasil kemampuan penalaran mahasiswa kelompok kontrol, sehingga dapat diketahui bahwa quantum teaching lebih berpengaruh secara signifikan daripada pembelajaran konvensional dalam meningkatkan kemampuan penalaran mahasiswa calon guru.

\section{KESIMPULAN}

Berdasarkan hasil pengolahan dan analisis data yang diperoleh, maka dapat diambil kesimpulan bahwa quantum teaching lebih baik dalam meningkatkan penalaran matematis mahasiswa dibandingkan pembelajaran konvensional, hal ini ditandai dengan terdapatnya perbedaan rerata skor posttes penalaran matematis mahasiswa antara kelompok eksperimen yang menggunakan quantum teaching dengan kelompok kontrol yang menggunakan pembelajaran konvensional. Sehingga quantum teaching dapat dijadikan alternatif yang efektif dalam meningkatkan kemampuan penalaran matematis mahasiswa calon guru.

\section{REKOMENDASI}

Berdasarkan hasil dalam penelitian ini, maka direkomendasikan bahwa pembelajaran sebaiknya menggunakan quantum teaching dalam mengajarkan matematika, siswa hendaknya dapat berperan aktif dalam proses pembelajaran dan hendaknya mencoba menciptakan lingkungan belajar yang efektif, dengan cara menggunakan unsur yang ada pada siswa dan lingkungan belajarnya melalui interaksi yang terjadi di dalam kelasinteraksi serta proses pembelajara yang tercipta akan berpengaruh besar sekali terhadap efektivitas dan antusiasme belajar pada peserta didik.

\section{DAFTAR PUSTAKA}

DePorter, B. \& Hernach, M. (2002). Quantum Learning: Membiasakan Belajar Nyaman dan Menyenangkan. Bandung: Kaifa.

Gintings, A.(2008). Esensi Praktis Belajar \& Pembelajaran. Bandung: Humaniora.

Herdian.(2010).Kemampuan Penalaran Matematika. [Online]. Diakses 01 Juni 2013.

Hermawan, W. (2007). Penerapan Metode Quantum Learning untuk Meningkatkan Hasil Belajar Mata Pelajaran IPA (SAINS). [Online].Diakses 01 Oktober 2013.

Nurkilah, A. (2009). Pengaruh Pembelajaran Quantum Learning terhadap Hasil Belajar Matematika Siswa SMP. Skripsi Sarjana Pendidikan Matematika Universitas Pasundan Bandung.Tidak diterbitkan. 
Nurwandiyanti, U. (2008). Peningkatan Pemahaman dan Reaktivitas Siswa dalam Pembelajaran Matematika melalui Quantum Teaching dan Quantum Learning. Skripsi Sarjana Pendidikan Matematika Universitas Muhammadiyah Surakarta.Tidak diterbitkan.

Ruseffendi, E.T. (2001). Pengaruh Penggunaan Kalkulator dalam Pengajaran Matematika di Sekolah Dasar terhadap Siswa dalam Belajar Matematika dan Pembelajaran Bukti dalam Geometri di Kelas Tiga Program Al SMUN X Bandung.

Ruseffendi, E.T. (2006). Pengantar kepada Membantu Guru Mengembangkan Kompetensinya dalam Pengajaran Matematika untuk Meningkatkan CBSA. Bandung: Tarsito.

Ruseffendi, E.T. (2010). Dasar-Dasar Penelitian Pendidikan \& Bidang Non-Eksakta Lainnya. Bandung: Tarsito.

Sugiono. (2013). Statistika untuk Penelitian. Bandung: Alfabeta.

Suherman, E., dkk. (1990). Petunjuk Praktis Untuk Melaksanakan Evaluasi Pendidikan Matematika. Bandung: Wijayakusumah 157.

Tim. (2013). Panduan Penyusunan Proposal Skripsi Skripsi dan Artikel Ilmiah. Bandung: Pelangi Press.

Usman, M. U.(1990). Menjadi Guru Profesional. Bandung: Remaja Rosdakarya. 